\title{
Civil Participation-Driven Social Capitalization-Enabled Resilience Cycle for Community-based Tourism
}

\author{
Chai Ching Tan \\ School of Management, Mae Fah Luang University \\ drcctan@yahoo.com, tan.cha@mfu.ac.th
}

\begin{abstract}
Community-based tourism (CBT) is flourishing in Thailand, partly credited to the active local participation and engagement-driven national policies that aim to stimulate effective uses of local resources and destination attributes for income-earning and sustainable socio-cultural and ecological development. Against this policy-grassroot synergistic backdrop and given the scare literature on the civil roles in CBT, this study examines the civil participation as an important social capitalization bridge to enable and thrust the community development and organization towards realizing CBT potentials while creating positive impacts on the economics, cultural, social and environmental domains of sustainability. In particular, a civil participation-driven social capitalization-enabled resilience cycle model, with a root taken to social capitalization structure of destination management that relates and integrates thestructural andrelational elements, and the cognitive goals, is proposed, as a key conceptual contribution to the extant literature of CBT and tourism, and is empirically supported by the neural network simulations and structural equation modeling (SEM) fitting. The samples were drawn from the agriculture- livelihood based communities who exploit community-based tourism (CBT) to supplement their earnings and help them develop socio-cultural and ecological attitudes and sustainability results. The SEM and the neural network results were well-aligned and cross-supportive, which manifests another domain of contribution in the methodological aspect in social sciences, tourism and hospitality disciplines. The resilience cycle model fit is dynamic in nature, and provides a base for the continuous development of the communities in sustainable manner
\end{abstract}

Keywords

Article Received: 10 August 2020, Revised: 25 October 2020, Accepted: 18 November 2020

\section{Introduction}

Tourism has been proven as an important instrument for economic and socio-cultural development, which can be effectively driven by destination's and its extended humansocial capital, and the participative governance systems (Fayos-Sola and Alvarez, 2014).As tourism industry shares a relatively large percentage of many nation's GDP (World Economic Forum, 2019), it is often treated as a political opportunity and means, which embraces civil society's participation as a key driving force in the tourism development process, partly attributable to making use of dialogue of people and opportunity for the development of mutual understanding of the people (Scott, 20212)in driving ahead to yield business outcomes. In fact, the significance of civil participation in tourism development has always been recognized in both practices and the academic fields (Lin and Simmons, 2017), which includes sensitizing to the grass-root voices as intellectual and practical sources for the dominant motivational forces, ideas, investments and supports.The inclusiveness of civil participation is emphasized in this study, which embraces the roles of the community members who are directly or indirectly involving with the community-based tourism (CBT) initiatives, the residents, the intellectually supporting mechanism of higher learning institutions, and the local government. These stakeholder participations become the necessary social capital or resources needed to enable and sustain agricultural livelihood, and equally important, to maintain the ecological health of the natural environment as fertile soil is the prerequisite for all the socio-cultural and economics happenings (Wondirad and Ewnetu, 2019).
Having involved civil actors, the tourism development process is believed to be better informed, which is more effective, equitable and legitimate (Murphy, 1988).To work effectively, many researchers point out a need to integrate the civil groups and networks within civil society with the state regulatory governments, and the networks within economic domains (Lin and Simmons, 2017), for the purposes, such as to protect local communities from tourism's adverse impacts (Jurowski, Uysal and Williams, 1997).In particular, the relevant civil or public actors must take on a proactive role in the formulation and implementation of the tourism destination plan (Lin and Simmons, 2017). These public or civil actors are essentially the local subjects involved in the destination management organizations (DMOs) or in any alternative modes of destination governance (d'Angella, de Carlo, and Sainaghi, 2010).

Albeit the significant roles of civil participation, abundant opportunities remain open to help clarify towards how the concept can be used to drive the communities toward developing community-based tourism (CBT) initiatives that can ultimately contribute to the sustainability assets, namely economics, socio-cultural and ecological healthiness. As these sustainability achievements are inseparable from where the communities live their life, these sustainability resources are also termed as livelihood assets (Colombo, Romeo, Mattarolo, Barbieri and Morazzo, 2018).

The research is thus set to study the roles of civil participation in supporting and driving CBT participation in supporting and driving CBT initiatives, by considering social capital and socio-cognitive theories, in identifying what other important lessons we can learn. 


\section{Literature Review}

This study conceptualizes civil participation, which includes communities, the government, and other relevant stakeholder supports such as tour operators and higher learning institutions, as the fundamental enabling force that provides the inspirational thrust and the program implementation efforts (Tan, Sitikarn and Anomasiri, 2018) to organize and develop the communities for realizing community-based tourism (CBT) values to the tourists, while simultaneously, accomplishing the sustainability goals. Seeing from this logical platform, social capital theory is robustly suited to operationalize any studies that involve the problems of development (Coleman, 1990). Concept of social capital has been advocated since the ancient time, which can be found in Max Weber's "The Protestant Sects and the Spirit of Capitalism" (Weber, 192021 ), and later in the 1960s are pioneered by the works of the French sociologist Pierre Bourdieu (Bourdieu, 1980), and has since, inspired substantial multidisciplinary research studies (Song and Lin, 2008; Trigilia, 2001).

According to social capital theory, as stated in Suebvises (2018), social capital including social networks and trusts, can foster public administrators to work closely with citizens and thereby can increase public sector performance (p. 237). In fact, civil participation is a necessary element of a new public governance or new public service idea that was based on the concept of democracy and citizenship participation as an essential precondition for effective performance. In general term, social capital depicts the actual and potential resources embedded within the relational network (Nahapiet and Ghoshal, 1998), which civil groups are a part. Typically, a social capital embraces three dimensions of variables, namely structural (i.e. the knowledge-driven structure), relational (including the psychological trust and affection) and cognitive (i.e. represented by the civil actors sharing the same ambitions and vision, and are enthusiastic about pursuing the collective goals and missions) (Kim, Lee, Paek, and Lee, 2013), as shown in Fig. 1. Civil actors are reckoned as important resource or capital to a tourism destination as they operate with distinct roles, capabilities, competences and powers (Franch, Martini, and Buffa, 2010), enabling success.

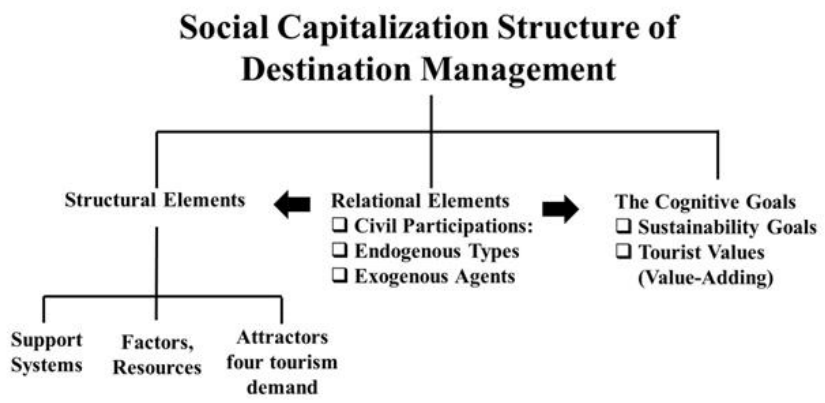

Fig. 1. A Social Capitalization Configuration of Destination Management

The social capitalization feature, as shown in Fig. 1, is enabled by the interrelationships among the civil actors within the tourism social-instrumental capital fabric linking the structural elements and the attraction offers in contributing to the destination competitiveness and sustainability. As tourism is a social business, the tourism positioning strategy would not be possible without the collective action of a sufficiently large majority of stakeholders, being endogenous and exogenous types:

- $\quad$ Endogenous types, consisted of local government corresponding to public administration instances operating at local level, private sector made of entrepreneurs, and residents, professional, and labor resources who are the agents permanently living in the destination and interacting with the tourists), and

- $\quad$ Exogenous agents, represented by customer and tourists, intermediaries and competitors external to the destination such as the tour operators, tourism agents and other intermediaries in the source markets, and supra-local government representing the public administration at a level higher than local).

Seeing the destination management as a social capitalization process and structure is a key contribution, inspired by the themes like "new sociology of economics development", i.e. ethnic entrepreneurship at the microlevel and state-society relations at the macro-level (Woolcock, 1998). The civil participation, as such, embraces the revelation of social capitalization characteristics as "embeddedness" (referring to intra-communities) and autonomy (extra-community networks) in driving ahead the "growth" phase. The "growth" stage is an initial phase in the development of resilience thinking, as advocated in Berbes-Blazquez and Scott (2017), which is represented by a set of community organization and development efforts being gradually developed to specialization. These activities include the structural elements, such as road conditions, transports, accommodation (homestays) and infrastructures such as communication means. This leads to the first hypothesis, $\mathrm{H} 1$ :

H1: Civil participation, represented inclusively by governmental role, stakeholder support, community leadership, participation in benefits and participation in implementation in preparation to move the CBT projects from the generalists to specialized phase, lead to influence positively the growth stage achievement represented by community organization and community development.

To be resilient and sustainable, many socio-cognitive theorists and researchers highlight a need of leadership. For instance, in Lew, $\mathrm{Wu}, \mathrm{Ni}$ and $\mathrm{Ng}$ (2017), they champion with their extensive case studies that to efficiently and speedily drive the changes for resilience at system-scale level, a systemic governance approach to sustainability and resilience is needed. Besides the governance structure, which enables the participation in benefits and implementation, leadership is also found, for instance, in Sheppard (2017), as a strong and effective governance system that, in turn, enables proactive responses to the critical events. In particular, Sheppard (2017) highlights the leadership roles in relation to nimbleness (better situated to deal with problems), receptiveness and willingness to listen to the community, supportive and being sensitive to the needs of the local community, business-like, and sensitive also to sustainability and business success. These characteristics are adapted in operationalizing leadership in the civil participation. 
The social capitalization enabled and adapted BerbesBlazaquez and Scott's (2017) resilience thinking and cycle is shown in Fig. 2, whichhas the civil participation to steer the growth process, and the ability of conservation to influence both the attitudes and beliefs of the community, and the values delivered to the tourists.In Habermasian communicative practice term, civil participation can be reckoned to possess a steering capacity to alter a social system by relying on communicative rationality and pursuing mutual understanding among participants (Munar, 2016) and the community of practices (CoP). By exploiting the concept of $\mathrm{CoP}$ as "the nexus linking culture, language, and worker/citizen development" (p. 81), and thus, the civil actor roles (O'Donnell et al. 2003: 81), we establish a gap to enrich the understanding of destination management and its space-variables structure design from the lens of civil participation, as, for instance, its community of practices. The civil participation is a democratic institution based on a viable multi-party system for decision-making decentralization and participation. Through decentralization, one can also motivate and enhance the level of local accountability, and develop the capacity to perform the needed functions at the right places (Shipley and Kovacs, 2008). There are also a host of ethical or moral relevancy in engaging actively with the civil groups, which can benefit sustainability culturally, economically, socially and ecologically. Shipley and Kovacs (2008) identify numerous important ethical domains, namely in balancing the exercise of powers granted to political leaders and managers, establishing equity, and foster collaborative spirit. This study thus centralizes on the civil participation in the hope to discover diversity of perceptual views of the civil actors to help understand the broader context and issue of destination management.

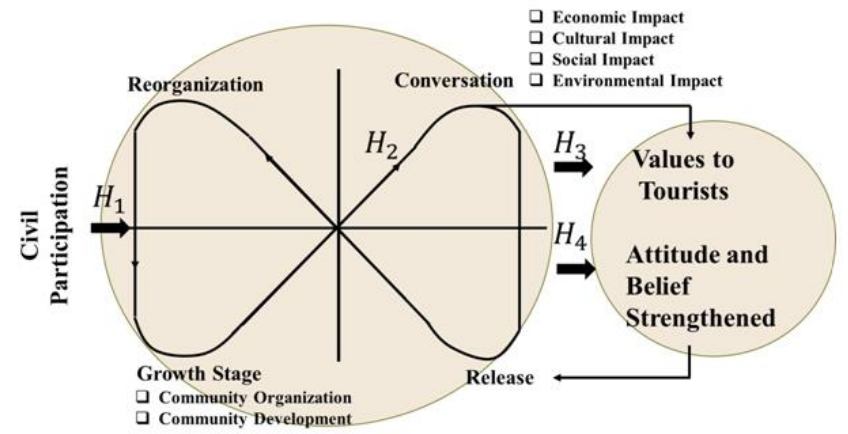

Fig. 2. A Civil Participation-Driven Social CapitalizationEnabled Resilience Cyclefor the Community-based Tourism (CBT) Development (The Conceptual Framework)

According to Berbes-Blazquez and Scott (2017), as the conservation stage progress, the connections between the elements of the system as depicted in the social capitalization-enabled resilience cycle become better defined, and it is at this stage that the social capital has shown its effectiveness. Accordingly, the second hypothesis is formed:

$\mathrm{H} 2$ : The growth stage, as depicted by the efforts of the community development and organization, would significantly able to explain the level of achievement in the four domains of sustainability, namely economics, social, cultural, and ecological.
Sustainability as livelihood has the nature of a collective good, not appropriated to individuals, but are enjoyed by all of those who participate in the activities (Coleman, 1990), and these are the fundamental motives and domains of values the tourists would obtain (Tan, Sitikarn and Anomasiri, 2018), leading to the third hypothesis, H3, stated as follows:

H3: The evidential sustainability achievements of the communities in their CBT efforts would form the base for the values to be delivered to tourists.

From the resilience and sustainable livelihood perspective, $\mathrm{H} 3$ also implies that the system is certainly more efficient at delivering the desired output, and is more capable of providing attractive and meaningful visitor experience for tourists.

In addition, by seeing the evidences of sustainability achievement, and from the evolutionary perspective on social psychological phenomena (Neuberg, Kenrick, and Schaller, 2010), the communities would interpret as more opportunities and less threats, which, then, form the heuristics base (Gigerenzer, Todd, and the ABC Research Group, 1999) for acceptance and further cognitive and behavioral support (Carlston and Skowronski, 2005) to the CBT initiatives. This social cognitive logic also shares what Bhattachargyya (2004) advocates on the themes of community development in an effort to ultimately increase solidary and agency. It is this social competence of community organization and development, together with the technical competence in the domain of CBT development, that ultimately enable change to succeed (Habermas, 1987). Thus, the fourth and last hypothesis is formed:

$\mathrm{H} 4$ : The sustainability achievement would further strengthen the attitude and belief of the community members towards the CBT initiatives.

As a closed loop closure, but the empirical validation would not be proceeded further, is a need for continuous feedback, which is seen at the "release" stage. The "release" stage highlights the fact that external disturbance or shock may push the system out of its operating range causing the original workable bonds to break and capital to be released. This prompts for re-organization which may require innovative ideas (Berbes-Blazquez and Scott, 2017). Thus, the continuous loop shown in Fig. 2 should enable the communities to be more resilient and sustainable, as manifested by the ability to shift from one equilibrium to another equilibrium state when encountering external triggers or shocks of significant levels. Fig. 3 depicts the resilience shift of equilibriums. 


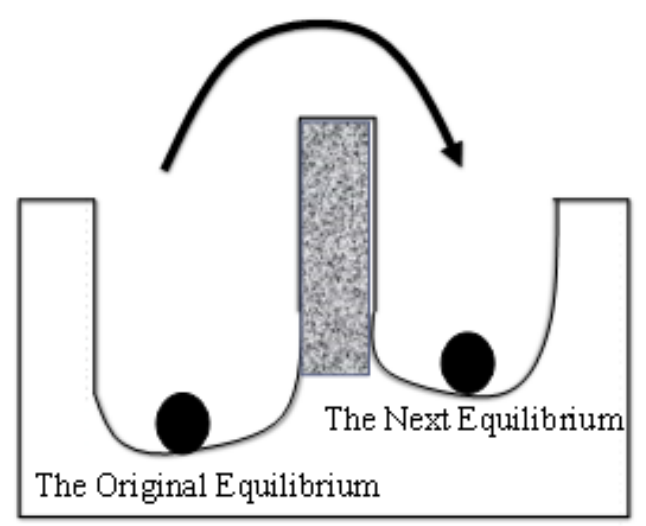

Es: Emerging Hurdles, Triggers or External Shocks

Fig. 3. The Resilience Shift of Equilibrium Triggering by External Shocks

\section{Method}

To test the research hypotheses, a questionnaire was developed in accordance with the definition to fit the constructs projecting the relevancy to the community-based tourism and destination context. To be exact, the questionnaire includes relevant demographics variables to describe the relevant community profiles and agricultural type as dominant livelihood, and the 13 constructsdrawn from questionnaire-based studies in domains of community participation (Wondirad and Ewentu, 2019), which includes community leadership (see Sheppard, 2017), and sustainable development (Lee and Jan, 2019), and social-cognitive explained community's attitudes and beliefs. Though attitude can be defined in a variety of ways, the core is the notion of evaluation (Petty, Wegener, and Fabrigar, 1997: 611 ) by the community members as evidenced in what they see in sustainability achievements. Accordingly, this study operationalizes using Eagly and Chaiken's definition on attitude, as "a psychological tendency that is expressed by evaluating a particular entity with some degree of favor or disfavor" (p. 1).

The perceived values offered to tourists are adapted from the studies explaining the experiential value of tourists which capture value dimensions such as functional, emotional, epistemic and social value (Varshneye and Das, 2017). Respondents were represented by the different stakeholders of the participating communities, which include community head, the farmers, the homestay owners, and anyone have ever served the CBT tourists. Apart from the nominal or categorical variables in demographics section, the respondents were asked to assess their agreeable degree in each statement of the theoretical modeling section by using five Likert response scale from 1 (strongly disagree) to 5 (strongly agree).

The questionnaire design was also carefully treated using dialogues with the community heads, to ensure simplicity, ease of comprehension and familiarity of language used. The reliability test was assessed to ensure conforming to the threshold criterion prior to further statistical analyses. A stringent reliability criterion of minimum of 0.80 Cronbach's alpha is used if the questionnaire design is rigorously processed (Hair, Anderson, Tatham, and Black,
2006). The validity and reliability characteristics of the questionnaires are discussed in the next section.

Basically, the survey was administered in person, with the help of numerous student assistants. Although questionnaires had already been pilot-tested with the community heads, there was still occasional need to explain to the community members when confusion arose. The target population consisted of the highland communities located in Chiang Rai and Nan provinces, who rely only coffee, tea or both crops as dominant livelihood, while community-based tourism (CBT) initiatives are supplementary. The surveys were distributed using purposive sampling as only those familiarize with the CBT activities can meaningfully respond, and they are only 5-10 members per community involved, accumulated to 176 in total, spanning two years of data collection.

Analysis was undertaken using structural equation modeling (SEM) technique and neural network simulation method, and employ mediation rationalization of Baron and Kenny (1986), and Judd and Kenny (1981).

\section{Results}

A total of 176 community members participated in the survey, which covers numerous coffee- and tea- livelihood based communities who also initiated community-based tourism (CBT) as complementary to their main coffee- and tea-crops. The scopes of the elements describing each of the constructs are given in Table 1, with the determined reliability index, as indicated by Cronbach's alpha 0.8 to 0.97 , indicates robust reliability of the construct instruments.

Table 1. Measurement Instrument and Reliability

\begin{tabular}{|c|c|c|}
\hline & Constructs & $\begin{array}{l}\text { Cronbach's } \\
\text { Alpha }\end{array}$ \\
\hline V1 & $\begin{array}{l}\text { Governmental role }- \text { infrastructural, } \\
\text { technical, budgetary, commercialization, } \\
\text { community needs supports. }\end{array}$ & 0.972 \\
\hline $\mathrm{V} 2$ & $\begin{array}{l}\text { Stakeholder support - private organization } \\
\text { support (technical and financial), university } \\
\text { support (research and development), and } \\
\text { non-government organization support. }\end{array}$ & 0.827 \\
\hline V3 & $\begin{array}{l}\text { Community leadership }- \text { inspiring } \\
\text { community members, equity, problem and } \\
\text { conflict solving, knowledge and } \\
\text { information dissemination, coordination, } \\
\text { operations guidance. } 0.943\end{array}$ & 0.943 \\
\hline V4 & $\begin{array}{llll}\begin{array}{l}\text { Participation } \\
\text { management }\end{array} & \text { in benefits }- & \text { Equity } \\
\end{array}$ & 0.866 \\
\hline V5 & $\begin{array}{l}\text { Participation in implementation - } \\
\text { Community members participated in } \\
\text { community-based tourism at various copes, } \\
\text { i.e. design, development, planning, } \\
\text { management, tourism activities. }\end{array}$ & 0.881 \\
\hline V6 & $\begin{array}{l}\text { Community organization }- \text { advisory } \\
\text { committee, shared ideology and sense of } \\
\text { community, fund and infrastructure } \\
\text { organization. }\end{array}$ & 0.881 \\
\hline V7 & $\begin{array}{l}\text { Community development }- \text { rules and } \\
\text { regulation, fair distribution and equity, } \\
\text { resident human resource development. }\end{array}$ & 0.907 \\
\hline V8 & Economic impact & 0.901 \\
\hline V9 & $\begin{array}{l}\text { Cultural impact - cultural preservation and } \\
\text { awareness increasing, knowledge }\end{array}$ & 0.848 \\
\hline
\end{tabular}




\begin{tabular}{|l|l|l|}
\hline V10 & $\begin{array}{l}\text { increasing, and cultural proudness. } \\
\text { Social impact - local resident skill and } \\
\text { personal development upgrade, wellbeing } \\
\text { and quality of life conditions, i.e. health, } \\
\text { education, and logistics and basic } \\
\text { infrastructure. }\end{array}$ & 0.86 \\
\hline V11 & $\begin{array}{l}\text { Environmental impact - sense of love and } \\
\text { awareness of ecological significance, waste } \\
\text { and water management, ecological } \\
\text { healthiness. }\end{array}$ & 0.868 \\
\hline V12 & $\begin{array}{l}\text { Attitude and Belief towards CBT - CBT } \\
\text { expansion as livelihood not able to dilute } \\
\text { and influence community's identity, and } \\
\text { moreover, can allow others to appreciate } \\
\text { and learn about community's uniqueness. }\end{array}$ & 0.814 \\
\hline V13 & $\begin{array}{l}\text { Community's perceptions of values offered } \\
\text { to tourists - Community's perceptions that } \\
\text { the CBT products and services can impact } \\
\text { memorable experiences to tourists, offer } \\
\text { tourists with useful knowledge (educational } \\
\text { value) relating to community's livelihood } \\
\text { means, and enable tourists to see how the } \\
\text { community can transform and serve the } \\
\text { tourists, and produce value-added products } \\
\text { and CBT services at the same time, cultural }\end{array}$ & \\
\hline
\end{tabular}

and heritage values, provide emotional touch to tourists.

On the post-data collected validity assessment, Table 2 testifies to both discriminant validity and convergent validity, being evidenced by the square-root of total variance explained (TVE) in amounts greater than the crosscorrelation coefficients of the constructs, TVE more than 0.60 , and cumulative reliability index more than 0.80 . Table 2 also shows the comparative significant differences of the constructs between the tea farming, coffee farming, or both crops-farming. The coffee farming communities, at the time of the data collection, show lower states of performances when compared to tea-cropped communities.

Table 2.Convergent Validity and Discriminant Validity Assessment

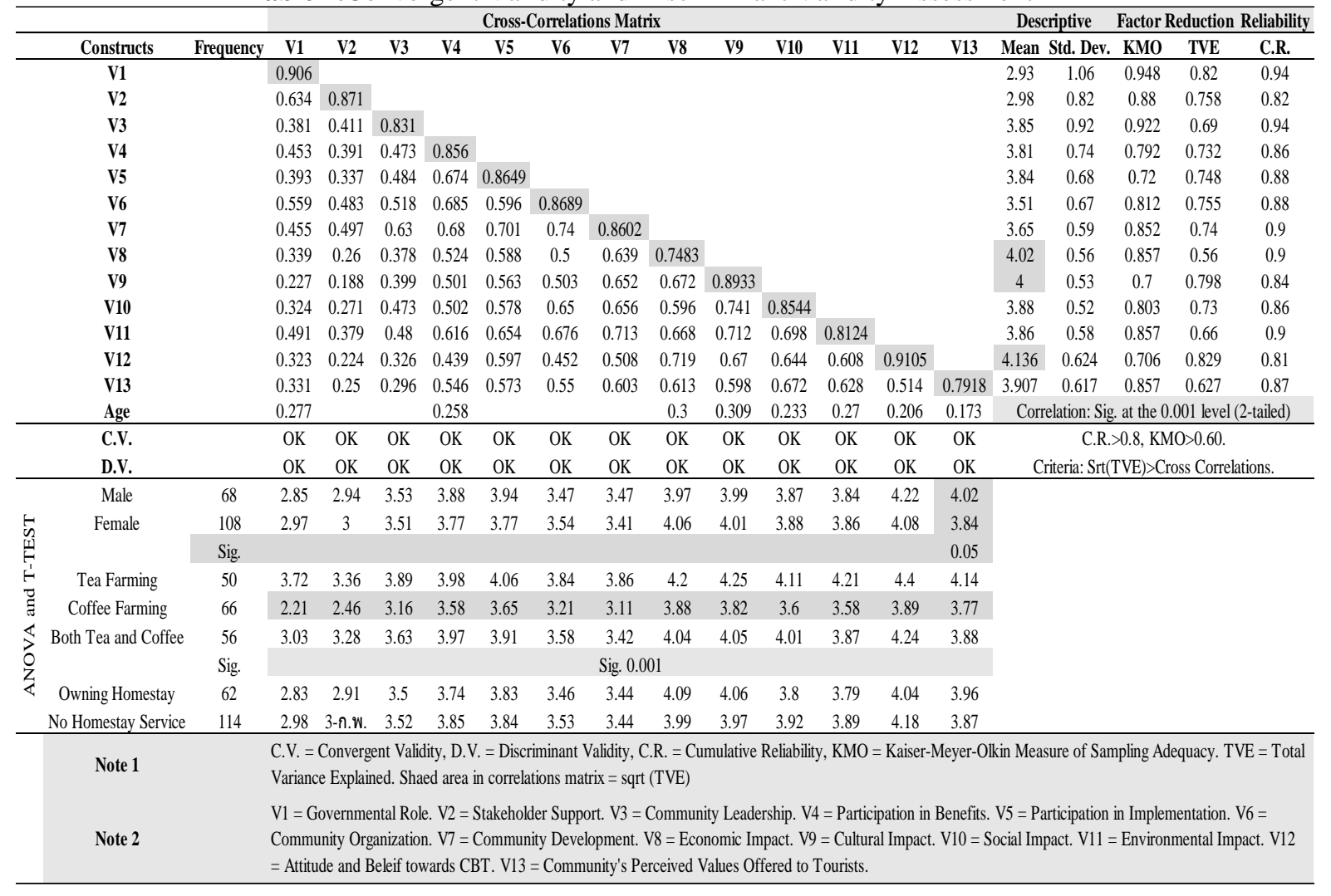

\section{Neural Network Simulation}

The neural network simulations were performed using multilayer perceptron approach. Table 3 predicts the economic impact, which conforms with the structural equation model (SEM) computation to follow. 
Table 3. Multilayer Perceptron Neural Network Training-Testing Set and Significant Weight Result for Predicting Economic

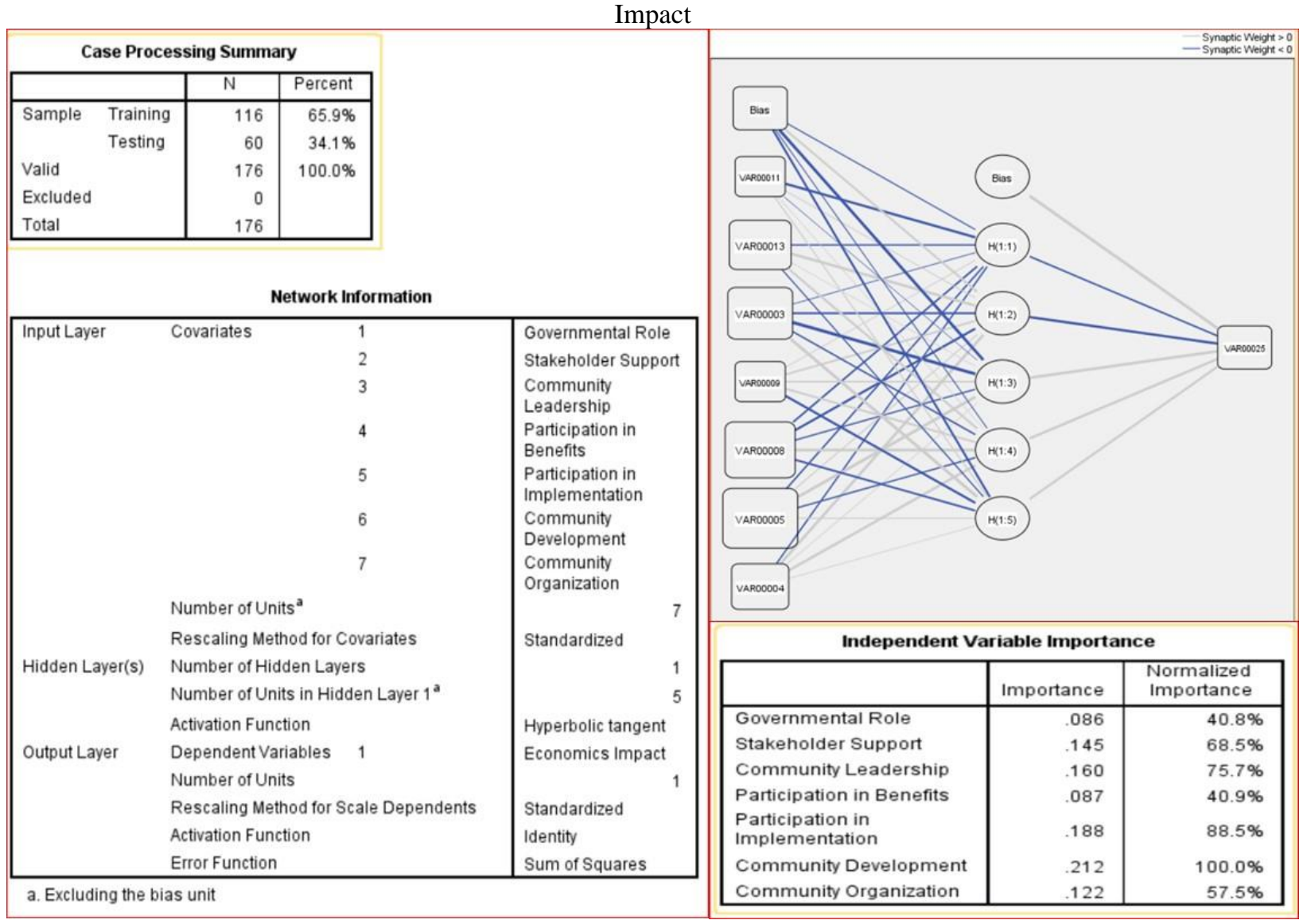

Note: V3 = Community leadership. V4 = Community organization. V5 = Community development. V8 = Participation in implementation. V11 = Government organization. V13 = Stakeholder support.
Table 4 is the next neural network simulation on predicting the perceived values offered to tourists, and again, the results are in alignment with the structural equation modeling (SEM) result to follow in the sequel.

Table 4. Multilayer Perceptron Neural Network Training-Testing Set and Significant Weight Result for Predicting Community's Perceived Values Delivered to Tourists

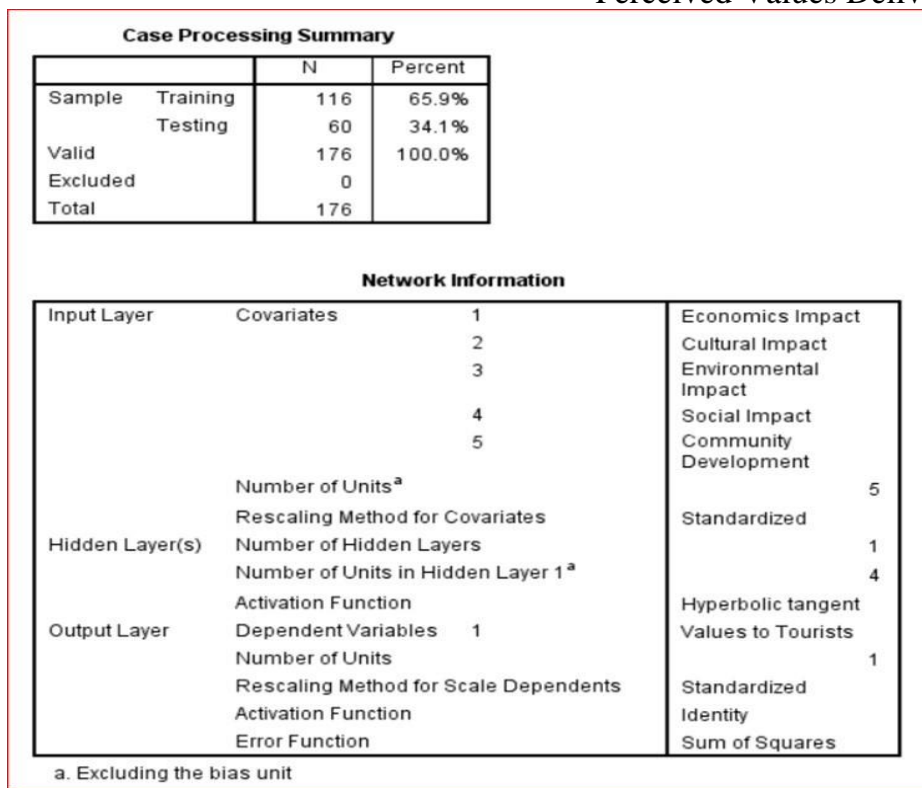

Note: V5 = Community Development. V25 = Economic Impact. V26 = Cultural Impact. V27 = Environmental Impact. V28 = Social Impact.

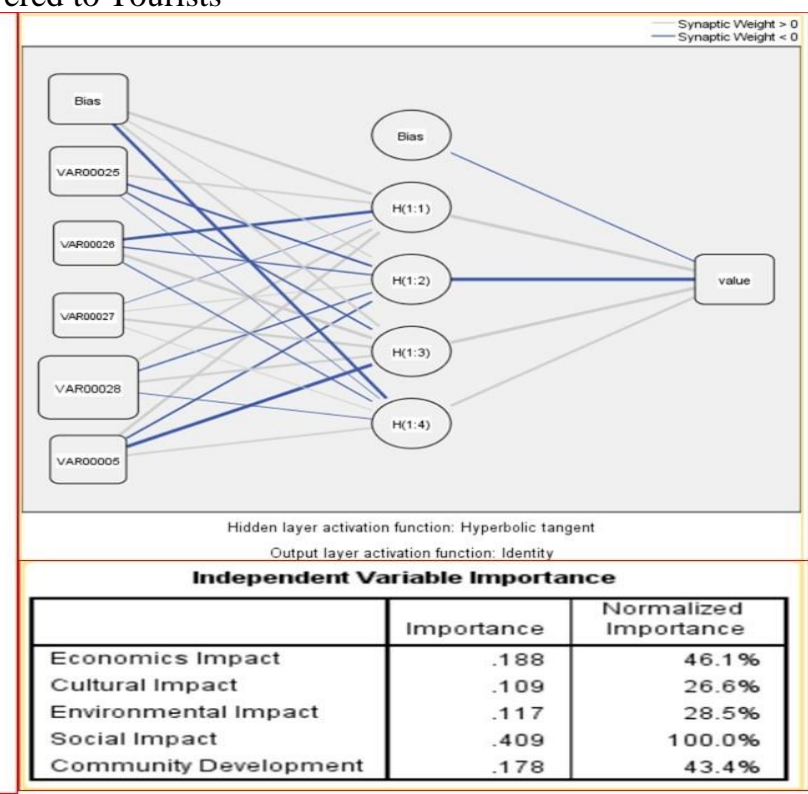

Being guided by the determinants-predictors structures predicted by the neural network simulation, the structural equation modeling (SEM) is then performed, which yields Fig. 2, with the variances of the corresponding predictors, namely economics impact, cultural impact, social impact, 
environmental impact, values to tourists, and attitude and belief towards CBT found at $0.45,0.54,0.66,0.58,0.55$ and 0.59 , and they are considered at high-power level. The robustness of the fits, both absolute and incremental, are also evidenced in Table 4, with the Chi-square/df at 1.101, at $\mathrm{p}$ insignificant at 0.317 , and RMSEA at 0.34 for confirming absolute model fit, and the incremental model fits evidenced by NFI at 0.957 , IFI at 0.996 , TLI at 0.990 and CFI at 0.996. In sum, the four hypotheses are supported.

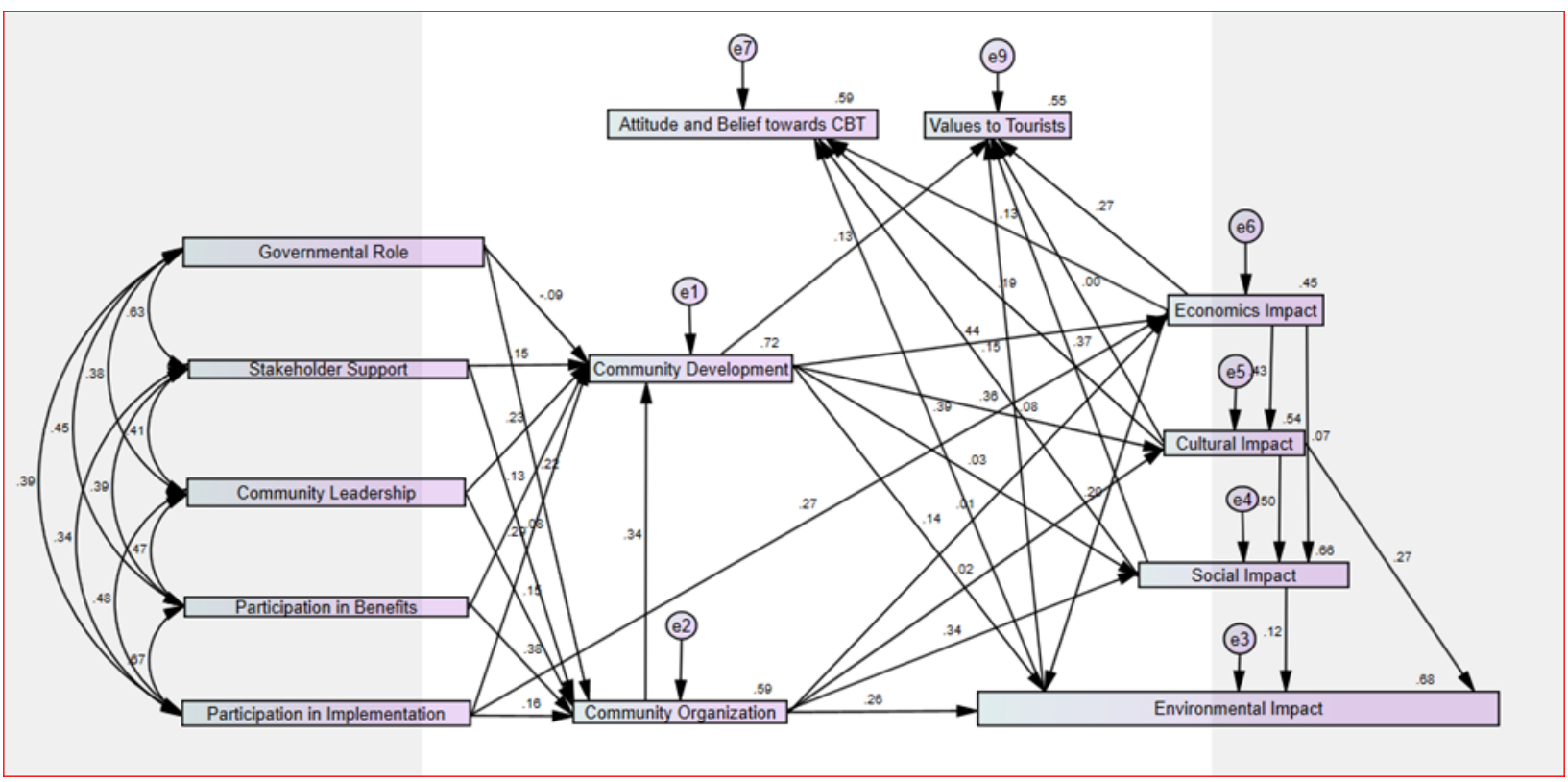

Fig. 2. The Empirical SEM Describing Civil Participation's Sustainability Impact on the Communities to local government) are considered the destination, and supra-. The processual aspect is also an empirical architecture aiming to create a new tourist destination.

The empirically validated SEM shares the similar outcome of neural network simulation. A closer look in Fig. 2 reveals the civil participation behaviors involved in making the destination attraction feasible and distinctively unique to the perceptual views of the tourists, which can be considered as a CBT destination creation and implementation system which possesses the necessary architectural components to steer participatory, management, organization and development behaviors for achieving shared goals developing CBT and delivering sustainability. The latter, sustainability achievement, is also acknowledge as the socalled livelihood assets (Colombo, Romeo, Mattarolo, Barbieri, and Morazzo, 2018).

In short, Fig. 2 covers both the structural elements (consisting of both endogenous and exogenous resources and factors, as characterized by the civil participation constructs on the left-hand side of the SEM) and delineates as well a dynamic process which establishes how these resources, mediated through community organization and development, in positively impacting on the sustainability domains, which further, influence the attitudes and beliefs of the community members, as well as the perceived values offered to the tourists (the design of tourist value proposition).Fayos-Sola, Moraleda and Mazon (2014) acknowledge the left-hand-side civil participation constructs as socio-institutional capitals, provided both endogenous (e.g. local government, private sector, residents, professional and labor resources) and exogenous resources (e.g./ customers/tourists, intermediaries and competitors external According to Balague and Brualla (2001), when one can reposition an existing geographical space or make the new geographical space holding interest for tourism consumers, for some obvious comparative advantages, whether of their business model, or destination image, or the resources possessed, including the supporting services, then, a "new destination" is formed.

Table 4. The SEM Test Statistics

\begin{tabular}{|c|c|c|c|c|c|}
\hline \multicolumn{6}{|l|}{ Melet be tementy } \\
\hline \multicolumn{6}{|l|}{ cuns } \\
\hline Moodel & NPAR & c)av & DF & $\mathbf{P}$ & CMINAPE \\
\hline Definh model & 71 & \multicolumn{2}{|c|}{36313} & 317 & t. $10 \mathrm{t}$ \\
\hline Sucurned nowet & 104 & 000 & $\infty 00$ & & \\
\hline islrgeolnace model & $\$ 6$ & \multicolumn{2}{|c|}{$\operatorname{kis} 32 \mathrm{n}$} & $\infty 000$ & to.tos \\
\hline \multicolumn{6}{|l|}{ 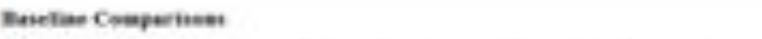 } \\
\hline Model & $\begin{aligned} \text { Nal } \\
\text { Dotal }\end{aligned}$ & Rat & $\begin{array}{l}\text { ut } \\
\text { Deltat }\end{array}$ & $\begin{array}{l}\text { ThI } \\
\text { mat }\end{array}$ & $\mathrm{CII}$ \\
\hline Definh moval & 957 & wa? & . Nos & 9 & 906 \\
\hline Satarased modet & 1000 & & 1.000 & & $t .000$ \\
\hline Islependerser medel & .000 & $\infty \infty$ & 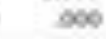 & $D \infty$ & 000 \\
\hline \multicolumn{6}{|l|}{ matse. } \\
\hline Model & \multicolumn{2}{|c|}{ RMESEA } & 1090 & 1990 & FCL.OSE \\
\hline Definctr nodel & \multicolumn{2}{|c|}{.034} & 600 & $\cos 8$ & 629 \\
\hline Indepeotirnoe model & \multicolumn{2}{|c|}{334} & 314 & 355 & 060 \\
\hline
\end{tabular}


The relationship plots of the some of the dominant predictors and determinants are shown in Fig. 3.
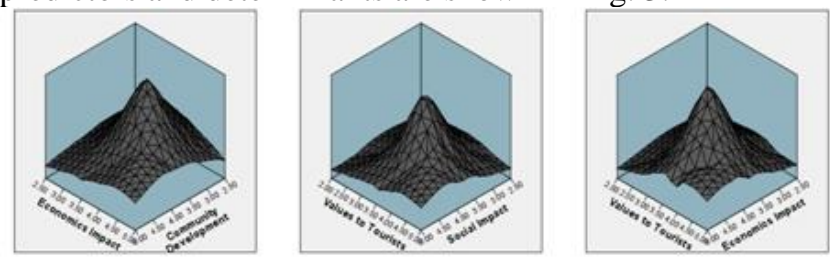

Fig.3. Multilayer Perceptron Neural Network Simulation Structure and Relationship between the Important Simulated Constructs

\section{Discussion}

This study examines the perceptually structured relationships of civil participation constructs, community organization and development, sustainability, attitude and belief of the community towards community-based tourism, and perceived values offered to tourists visiting the communities. Civil participation constructs found to significantly able to influence the scopes and level of community organization include the role of government, the relevant stakeholder supports such as the universities, tour agents and private sectors, and the community consisting of community leadership, participation of the community members in both benefits and the implementation process. The involvement of civil agents, and the community and relevantly participating stakeholders are not straightforward. While this research empirically confirms that these participatory actions do provide the thrust, fund, motivation, and ideas to facilitate the community to proceed to organization, which establishes the necessary working teams, and to contribute to formulating and implementing tourism as a tool for sustainable development of the community, other researches bring attention to balance of power consideration, the stakes at hand (Dominguez-Gomez and Gonzalez-Gomez, 2017). Though there are subtle differences in each research effort, nevertheless, community participation is indeed at the heart of sustainable development (Kebete and Wondirad, 2019). On the other hand, the civil society's role is rather unclear, which this research fills the gap and which has also attracted the renewed interest of both policy makers at the governmental level and the researchers (Vergopoupos, 2018).

Another important finding is that perceived sustainability impact to the community in influencing the socio-cognitive perceptions of the community members and the values the members can offer to the potential tourists. From the view of ethics, this assertion can be explained to project both the instrumental value and intrinsic value of the CBT development. The former involves as a means to make CBT end happened, and the latter is inherently a good end in itself (Curry, 2011). The extant literature often considers attitudes and beliefs as antecedent to sustainability (Tan et al. 2018), but this research treats it as posterior formation, by following the sociological routes of gradual attitudinal formation (Sawyer, 2007). If the community can establish the sensitivity to this antecedent-posterior interrelationship between sustainability and attitudes, it can help project a more fact-driven approach to "sustainable growth" or "sustainable development", as growth in a finite physical world would necessarily reaches a point where it is no longer sustainable (Curry, 2011: 228).

\section{Conclusion}

The empirically validated roles of civil agents, the community members' participations and the supporting stakeholders like the private tour agents and universities in enabling and driving both community organization and development for the sustainable development of the community, point to a significant area of implication. That is, if these stakeholders do purposively, cohesively, and organizationally revolve and bind around shared interest and passion, the concepts and theories of communities of practice $(\mathrm{CoP})$ can be tapped on. In other words, through shared commitment, the relevant stakeholders can form a working group to develop and exploit intellectual capital (Volpel, 2002) as they gain more experiences through dialogues and conversations, sharing the "communicative logic" of Habermas (1984), to discover and deliver values in sustainable manner to the tourists, the community, and also to stimulate sectoral linkages or consolidating value chain to the community-based tourism initiatives (Stone and Stone, 2011). Through establishing the communicative platform (Lutterer, 2007), possibility of success is increased as actions are taken and invested (Tan et al., 2018).

Another obvious implication of this research finding is that the SEM-cum-neural network validated model can be served as a springboard for undertaking further research and policy decisions in destination governance, by stressing on the active interaction aspect. To be exact, interaction is an inexplicable human side of any governance issues, whether for corporate or destination (Huse, 2007).

There is not without limitation for this research. Fayos-Sola, Moraleda, and Mazon (2014) present two types of agents typically involved in a destination development, namely the endogenous type (consisting of local government, private sector, residents), and exogenous types (consisting of customers/tourists, intermediaries and competitors external to the destination, and supra-local government), in order to establish a systemic perspective take can more systematically tap on the available social-institutional capital fabric of the society, the market and the industry. In this research, the exogeneous aspect of participating agents is not incorporated in the questionnaire design. In addition, there are various other livelihood types which communitybased tourism can rely and has relied upon in the areas the communities are located, but this research focuses on only coffees and teas farming as sources of livelihood. In this regard, the generalization of this research is best fitted to this context. Nevertheless, judging from the nature of community and its ecological richness environment, the SEM-validated framework is deemed conceptually relevant, such as relating to socio-cognitive theory (Tan et al. 2018), or cybernetic psychology (2011).

\section{Implications}

First, the explicit structure of social capitalization process, as indicated in the resilience cycle, turns the invisible hand of social capital (Lin and Ao, 2008) into organized use. Second, the empirically validated structure provides the 
development of resilience thinking and development to tourism involving the civil actors, and are targeted as ultimate value motives for the visitors intended to experience community's agricultural livelihood and tourism experiences.

\section{References}

[1] Balague, J., Brualla, P. (2001). La Planificacion del destinoturiscoen el siglo xxi. Educatur la gestion eficaz de un destinoturisticodels, XXI, Barcelona, 5597.

[2] Baron, R.M., \& Kenny, D.A. (1986). The moderator-mediator variable distinction in social psychological research: Conceptual, strategic and statistical consideration. Journal of Personality and Social Psychology, 51, 1173-1182.

[3] Berbes-Blazquez, M., \& Scott, D. (2017). The development of resilience thinking. In R.W. Butler (Ed.). Tourism and resilience (pp. 9-22). Oxfordshire, UK: CABI.

[4] Bhattacharyya, J. (2004). Theorizing community development. Journal of the Community Development Society, 34(2), 5-34.

[5] Bourdieu, P. (1980). Le capital social: notes provisoires. Actes de la recherche en sciences sociales, 31, 2-3.

[6] Carlston, D.E., \&Skowronski, J.J. (2005). Linking versus thinking: Evidence for the different associative and attributional bases of spontaneous trait transference and spontaneous trait inference. Journal of Personality and Social Psychology, 89, 884-898.

[7] Coleman, J. (1990). Foundations of social theory. Cambridge, MA: Harvard University Press.

[8] Colombo, E., Romeo, F., Mattarolo, L., Barbieri, J., \&Morazzo, M. (2018). An impact evaluation framework based on sustainable livelihoods for energy development projects: an application to Ethiopia. Energy Research \& Social Science, 39, 78-92.
[9] Curry, P. (2011). Ecological ethics: An introduction. Cambridge, UK: Polity Press.

[10] D’Angella, F., De Carlo, M., \&Sainaghi, R. (2010). Archetypes of destination governance: A comparison of international destinations. Tourism Review, 65(4), 6173.

[11] Dominguez, J.A., \& Gonzalez-Gomez, T. (2017). Analyzing stakeholder perceptions of golf-course-based tourism: a proposal for developing sustainable tourism projects. Tourism Management, 63, 135143.

[12] Eagly, A.H., \&Chaiken, S. (1993). The psychology of attitudes. Orlando, FL: Harcourt Brace Jovanovich College Publishers.

[13] Fayos-Sola, E., Moraleda, L.F., \&Mazon, A.I.M. (2014). The FAST model: Destination analysis and governance. In Tourism as an instrument for development: A theoretical and practical study bridging tourism theory and practice, 5, 55-86.

[14] Franch, M., Martini, U., \& Buffa, F. (2010). Roles and opinions of primary and secondary stakeholders with communitytype destinations. Tourism Review, 65(4), 75-86.

[15] Gigerenzer, G., Todd, P.M., \& The ABC Research Group (1999). Simple heuristics that make us smart. New York: Oxford University Press.

[16] Habermas, J. (1984). The theory of communicative action: reason and the rationalization of society, Cambridge: Polity.

[17] Habermas, J. (1987). The theory of communicative action, vol. 2, lifeworld and system: a critique of functionalist reason. Boston, MA: Beacon Press.

[18] Hair, J.F., Anderson, R.E., Ratham, R.L., \& Black, W.C. (2006). Multivariate data analytics. Englewood Cliffs, NJ: Pearson International. 
[19] Huse, M. (2007). Boards, governance and value creation. Cambridge, UK: Cambridge University Press.

[20] Judd, C.M., \& Kenny, D.A. (1981). Process analysis: Assessing mediation in treatment evaluations. Evaluation Review, 5, 602-619.

[21] Jurowski, C., Uysal, M., \& Williams, D.R. (1997). A theoretical analysis of host community resident reactions to tourism. Journal of Travel Research, 36(2), 3-11.

[22] Kebete, Y., \&Wondirad, A. (2019). Visitor management and sustainable destination management nexus in Zegie Peninsula, Northern Ethipia. Journal of Destination Marketing Management, 13, 83-98.

[23] Kim, T.T., Lee, G., Paek, S., and Lee, S. (2013). Social capital, knowledge sharing and organizational performance: What structural relationship do they have in hotels. International Journal of Contemporary Hospitality Management, 25(5), 683-704.

[24] Lee, T.H., \& Jan, F.H. (2019). Can community-based tourism contribute to sustainable development? Evidence from residents' perceptions of the sustainability. Tourism Management, 70, 368-380.

[25] Lew, A.A., Wu, T.C., Ni, C.N., \& Ng, P.T. (2017). Community tourism resilience. Some applications of the scale, change and resilience (SCR) model. In R.W. Butler (Ed.). Tourism and resilience (pp. 23-37). Oxfordshire, UK: CABI.

[26] Lin, D., \& Simmons, D. (2017). Structured inter-network collaboration: Public participation in tourism planning in Southern China. Tourism Management, 63, 315-328.

[27] Lin, N., \&Ao, D. (2008). The invisible hand of social capital: An exploratory study. In N. Lin (Ed.). Social capital: critical concepts in the social sciences (volume IV, pp. 283-312). New York, NY: Routledge.

[28] Lutterer, W. (2007). The two beginnings of communication theory. Kybernetes, 36(7/8) 1022-1025.
[29] Munar, A.M. (2016). The house of tourism studies and the systemic paradigm. In Tourism Research Paradigms: Critical and emergent knowledge. Published online 01 June 2016, 131-153. Http://dx/doi/org/10.1108/S15171504320150000022014/.

[30] Murphy, P.E. (1988). Community driven tourism planning. Tourism Management, 9(2), 96-104.

[31] Nahapiet, J., \& Ghoshal, S. (1998). Social capital, intellectual capital and organizational advantage. Academy of Management Review, 23(2), 242-266.

[32] Neuberg, S.L., Kenrick, D.T., and Schaller, M. (2010). Chapter 21. Evolutionary social psychology. In S.T. Fiske, D.T. Gilbert, \& G. Lindzey (Eds.). Handbook of Social Psychology (pp. 761796). Hobooken, New Jersey: John Wiley $\&$ Sons.

[33]

[34] O’Donnell, D., Porter, G., McGuire, D., Garavan, T.N., Heffernan, M., \& Cleary, P. (2003). Creating intellectual capital: A Habermasian community of practice (CoP) introduction. Journal of European Industrial Training, 27(2/3/4), 80-87.

[35] Petty, R.E., Wegener, D.T., \&Fabrigar, L.R. (1997). Attitudes and attitude change. Annual Review of Psychology, 48, 609647.

[36] Sawyer, R. (2007). Social emergence: Societies as complex systems. Cambridge: Cambridge University Press.

[37] Scott, B. (2011). Toward a cybernetic psychology. Kybernetes, 40(9/10), 12471257.

[38] Scott, J. (2012). Tourism, civil society and peace in Cyprus. Annals of Tourism Research, 39(4), 2114-2132.

[39] Shipley, R., \& Kovacs, J.F. (2008). Good governance principles for the cultural heritage sector: lessons from international experience. Corporate Governance, 8(2), 214-228. 
[40] Song, L., \& Lin, N. (2008). Social capital and health. In N. Lin (Ed.). Social capital: critical concepts in the social sciences (volume IV, pp. 283-312). New York, NY: Routledge.

[41] Sheppard, V.A. (2017). Resilience and destination governance: Whistler, BC. In R.W. Butler (Ed.). Tourism and resilience (pp. 69-80). Oxfordshire, UK: CABI.

[42] Stone, L.S., \& Stone, T.M. (2011). Community-based tourism enterprises: challenges and prospects for community participation: Khama Rhino Sanctuary Trust. Botswana Journal of Sustainable Tourism, 19(1), 97-114.

[43] Suebvises, P. (2018). Social capital, citizen participation in public administration, and public sector performance in Thailand. World Development, 109, 26-248.

[44] Tan, C.C., Sitikarn, B., \&Anomasiri, S. (2018). A social psychological cybernetics model of entrepreneurial community-based tourism initiatives. Journal of Mekong Societies, 40(2), 21-46.

[45] Varshneye, G., \& Das, G. (2017). Experiential value: Multi-item scale development and validation. Journal of Retailing and Consumer Services, 34, 4857.

[46] Vergopoulos, H. (2018). Alternative tourism and civil society in Athens. International Journal of Tourism Cities, https://doi.org/10.1108/IJTC-12-20170086.

[47] Volpel, S.C. (2002). Strategic intellectual capital creation: decontextualizing strategy research. Journal of Intellectual Capital, 3(2), 118-127.

[48] Weber, M.

(1920-21). GesammelteAuftazeZurReligionsoziologie . Tubingen Mohr.

[49] Wondirad, A., \&Ewnetu, B. (2019). Community participation in tourism development as a tool to foster sustainable land and resource use practices in a national park milieu. Land Use Policy, 88, 104155.
[50] World Economic Forum (2019). The Travel \& Tourism Competitiveness Report 2019. Geneva: World Economic Forum. 